\title{
GST Effect on Manufacturing Industry - India
}

\author{
Dr. P. Mahender \\ Department of Business Management, \\ Osmania University, Hyderabad, India
}

\begin{abstract}
Every nation will impose various taxes on people and thing in order to undertake developmental work. In India the government of India recently enacted a law namely GST. This paper seeks to explain the positive and negative effects of GST on manufacturing industry in India.
\end{abstract}

Keywords: GST Manufacturing industry, Pharmacy, Revenue, Automobile, Consumer

\section{INTRODUCTION}

GST means Goods and Services Tax. It had been introduced by p Chidambaram was a Finance minister from 2008 to 2010. Actually it is an indirect tax on the manufacturing goods .the GST was replaced by VAT (value added tax). The main aim is to collect systematic tax on listed goods. The GST bill was passed by the Indian parliament,

The GST effect on share market with positive effect the market which are FMCG, Automobile, Cement, Light electrical, multi flex, Rail and Logistics departments could in future.

\section{REVIEW OF LITERATURE}

Das and Gupta (2004): They stated that the tax compliance can be improved by implementing simple reforms in personnel policy in Indian income tax .He concluded that the GST will lead to higher tax compliance and lower tax evasion by Indians.

Gang and Ira N (2000): They concluded that the tax structure India, some tax structure changes were implemented to reduce tax evasion.

Thirupathi and Sweta (2011): They examined VAT is a type of indirect tax that is imposed on goods and services, and they advocated the tax impact on budget and revenue

Sijbren (2013): Sijbren and others suggested, A modern goods and services to alleviate the problems of India's current indirect tax system.

\section{OBJECTIVES OF THE STUDY}

The primary objectives of the study are effeteness on different types of manufacturing goods and services. It is a scientific tax system approach .It could be useful to increase the revenue of the country, and enhance the nation's wealth and abolish the absence of tax payment. The concept of GST is "One tax and one Nation".

To reduce the burden of tax between state and the center

To enhance of revenue through the GST as one tax

To encourage to the manufacturing industry in India

To abolish the absence of tax payment in India

Scope of the study: Goods and services tax has vast scope. The scope will cover listed number of items under the coverage of tax area only. 
Hypothesis: The hypothesis should be to certify whether GST is applicable to manufacturing industry. It is useful / support to popularise the make in India.

Null hypothesis: The goods and services tax is risk based task and the revenue system has been under the control of central government.

Alternative hypothesis: The burden of risk management should bear the central government the revenue should distribute based on state and central government ratios.

Data sources and methodology: The data source is based on primary and secondary data. Basically the secondary data has been collected from the concerned departmental records, magazines, journals and news papers. The primary data information has been gathered from the official of departmental personnel opinions and views. The methodology is based on observation method only.

\section{ANALYSIS OF THE GST}

\section{The Effect of the GST on Manufacturing Industry in India}

Cement industry: Cement industry is the one of oldest manufacturing industry the industry has the greatest historical background. Where the civilization is there is role of the cement, make in India concept applicable for this industry. The industry has some indirect taxes. By the GST effect the cement industry has indirect tax which might be subsume as 16\% to $20 \%$.currently tax burden of indirect taxes from $27 \%$ to $32 \%$ decrease of tax rate as $16 \%$ to $20 \%$ it my create /facilitate as operating expenses such as transportation expenses benefits that the subsume of expenses the industry can claim the above benefits in future.

Automobile Industry: At presently automobile industry payment of the tax sum of $30 \%$ to $47 \%$ the effect of GST the tax rate decrease from $20 \%$ to $22 \%$ so at least the consumer may get the benefits.

Consumer and Durable Sector: Currently the consumer and durable claiming revenue net tax total tax percent is 7 to 30 , the sector had been exempted from such taxes so the effect of GST, the industry would have to get the benefits. The defference between organized and un organized Sectors is that the rates gap may sub sum. Warehousing and logistics expenses may reduce C.G.C.E Havel, Voltas, Blue star Bajaj electricalsimfani, Hitachi, etc companies are benefited by the effect of GST.

IT\&IT IS: In the India IT sector 50 percent to 70 percent of the graduates depend on the only IT sector. The net tax rate is $14 \%$. By the implementation of GST the tax may be $18 \%$ to $20 \%$ to increase. In IT sector the revenue is mainly depending on only export of IT products and services revenue of IT export exempted from the GST. So the GST effect is to be Negative.

Telecom sector: The telecom sectors presently the tax rate is $14 \%$.By the causes of GST the tax rate on telecom sector would have to increase as $18 \%$. So the result of GST on telecom sector will be negative. The public sector is to be critical. In future the concept of "one tax and one nation" caption is not suitable for Telecom sector.

Banking and Financial services: Banking is heart of financial India (wealth). In India public and private banking industry is the reflection of mixed economy. The banking sector's net tax rate is $14 \%$ by the effect of GST the rate will be increased from $18 \%$ to 20 . That the differential tax rate causes as Loan fees, debt and credit charges, insurance premium, etc the financial services charges burden on customers will increase. So the GST will also influence on customer purchasing power. In the banking business transactions will have also effect on share market.

Pharmacy industry: The pharmacy sector are getting exemptions regional wise. The excise tax rate is $6 \%$. Till the end of the duration the subsidies will have to continue, then after that they will not available. The new tax pattern the industry could not remain constant it is considerable because the encouragement of pharmacy sector

Textile and garment industry: Emerging industry has playing key role in textile and garments .That the industry has recipient of tax rate is currently from $6 \%$ to $7 \%$ that tax rate may or may not be continued it is clear in that process the output of tax rate may hick by the effect of GST which is negative .the textile sector enjoy some of few companies like page industry, Aravind, Raymond etc.

DTH/Media company: DTH and media sector's average tax payment rate presently $19 \%$ to $21 \%$ apart from that service tax is $14 \%$, entertainment tax is $5 \%$ to $7 \%$ Brad costing companies are paying 
tax rate is $14 \%$ to $15 \%$ these two departmental taxes are effect by the GST $18 \%$ to $20 \%$.Currently news and print media has been exempted from that taxes, the GST prove to DTH and some Negative to print media and braudcosting. Dish TV may get benefits ZEE sun HT media prakesh jagaran to negative.

Automobile and Batteries industry: The field of Batteries would have face the throat cut competition by the effect of GST Jumbo feasibilities it has the effect on "the transported vehicles may get the benefits by the GST.

\section{Conclusions of The Study}

Indian business scenario manufacturing industry is the playing significant role, in business world. In the world every country has the sum of financial or aid to the manufacturing industry. Some companies feel like that Agriculture crop within the duration. Manufacturing sector is economic growth of nation. When the country focus on manufacturing industry that the country overcomes technological barriers.

- The cemetery industry can enjoy operating and transportation expenses by the effect of GST.

- Automobile industry, also getting benefits by the GST, according to subsum of taxes.

- Consumer and durable sector also reduces where housing expenses by the effect of GST.

- $\quad$ IT and IT IS sector the GST effect is negative.

- Telecom and banking and financial services must face the operating expenses risk.

- The Indian pharmacy seek encouragement from the government, but the excise tax rate is $6 \%$ as an the date.

- Textile and garment industry face negative impact by the GST.

- Media companies also (DTH) may also have negative scenario.

\section{REFERENCES}

[1] Cnossen, Sijbren (2013):"Preparing the way for a modern GST in India" in "International Tax and Public Finance",Aug 2013 Springer Science \& Business Media (New York).

[2] Das-Gupta, Arindam; Gang, Ira N (2000): "Decomposing Revenue Effects of Tax Evasion and Tax Structure Changes" in "International Tax and Public Finance",March, 2000, Springer Science \& Business Media(New York).

[3] Das-Gupta, Arindam; Ghosh, Shanto; Mookherjee, Dilip, (2004):" Tax Administration Reform and Taxpayer Compliance in India" in "International Tax and Public Finance",September, 2004, Springer Science \& Business Media(New York).

[4] Dash, Bharatee Bhusana; Raja, Angara V(2013):"Intergovernmental Transfers and Tax Collection in India: Does the Composition of Transfers Matter?" In "Public Budgeting \& Finance",Blackwell Publishing Ltd(Maiden).

[5] Eigner, Richard M (1959):" Business And Economics-Public Finance, Taxation, Political Science" in "National Tax Journal”,June, 1959 , National Tax Association (Washington)

[6] Goode, Richard (1956):"Report of the India taxation enquiry commission"in "National Tax Journal",June, 1956, National Tax Association(Washington)

[7] Har Govind (2005):"'Important Fiscal Changes and Tax Developments in India through the Finance Act 2005" in "Intertax", November, 2005, Springer Science \& Business Media (Deventer).

[8] Jayaraman Vijayakumar; Rasheed, Abdul A; Krishnan, V S (2005):"Corruption and taxation: lessons from the indian experience"in "Journal of Public Budgeting, Accounting \& Financial Management",Academics Press, Florida Atlantic University(Boca Raton).

[9] Ketkar, Kusum W; Murtuza, Athar; Ketkar, Suhas L (2005),:"'Impact of corruption on foreign direct investment and tax revenues"in "Journal of Public Budgeting, Accounting \& Financial Management”,Academics Press, Florida Atlantic University (Boca Raton). 